\title{
Atherosclerotic Biomarkers (Interleukin-6 and CD40) and Tunica Intima Thickness in Obese Rats after the Administration of Plectranthus amboinicus (Lour.) Spreng Ethanol Extract
}

\author{
Karnirius Harefa ${ }^{1}$, Delmi Sulastri ${ }^{1}$, Ellyza Nasrul ${ }^{1}$, Syafruddin Ilyas ${ }^{2 *}$ \\ ${ }^{1}$ Study Program of Biomedic, Faculty of Medicine, Universitas Andalas, Padang, Indonesia; ${ }^{2}$ Department of Biology, Faculty of \\ Mathematics and Natural Sciences, Universitas Sumatera Utara, Medan, Indonesia
}

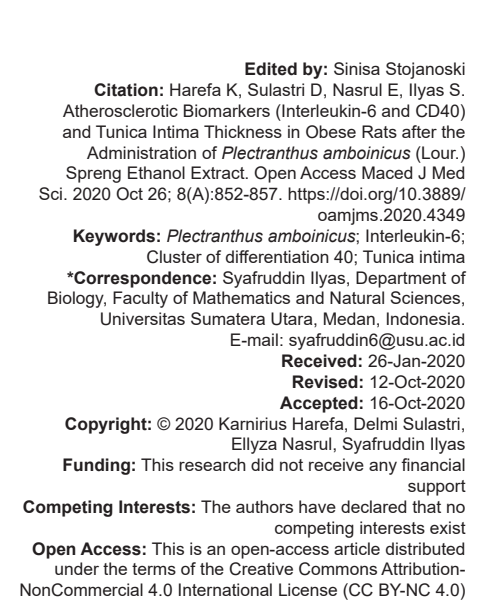

\begin{abstract}
BACKGROUND: Obesity can increase oxidative stress, thereby increasing the inflammatory markers interleukin (IL)-6. These markers are characterized by various biomarkers, such as cluster of differentiation 40 (CD40) and IL-6 and thickness of the tunica intima.

AIM: This study aims to analyze the effect of the Plectranthus amboinicus (Lour.) Spreng ethanol extract on IL-6 $\mathrm{CD} 40$, and thickening of the tunica intima of obese rats.

METHODS: The pure experimental method with complete random design consisted of several research groups: C- (negative control), C+ (positive control/cholesterol feed), positive control (cholesterol feed + CMC), T1 Chol 300 (cholesterol feed and administration of $300 \mathrm{mg} / \mathrm{kg}$ body weight [BW] P. amboinicus for 45 days), T2_Chol_600 (cholesterol feed and administration of $600 \mathrm{mg} / \mathrm{kg}$ BW P. amboinicus for 45 days), and T3_chol_900 (cholesterol feed and administration of $900 \mathrm{mg} / \mathrm{kg}$ BW P. amboinicus for 45 days).

RESULTS: Results showed increased CD40 levels in the blood plasma of obese rats and decreased CD40 levels after the administration of the ethanol extract of P. amboinicus leaves. A significantly increased $(p<0.05)$ level of IL-6 in the obese mice group and a significant decrease $(p<0.05)$ in IL-6 after the administration of the ethanol extract of $P$. amboinicus leaves were observed. Tunica intima thickness significantly occurred $(p<0.05)$ in the group of obese rats, and normal tunica intima thickness occurred in the group administered with the ethanol extract of $P$. amboinicus leaves.

CONCLUSION: In conclusion, the ethanol extract of P. amboinicus leaves (900 mg/kg BW) had the potential to normalize obese rats.
\end{abstract}

\section{Introduction}

The changes in the mode of transportation, increased urbanization, and mechanization that occurs in most countries are associated with obesity. An increasing number of people who are less active and change in the diet, particularly in eating high-fat foods, are observed [1]. Asians have a high incidence of obesity due to their less physical activity compared with Europeans. Asians tend to have central obesity and a higher fat percentage than body mass index (BMI) measurements proportional to the increase in cardiovascular disease based on the declaration of agreement by the pacific regional office of WHO with overweight (BMI: 23.0-24.9) and obese (BMI> 25.0) definitions for the Asian population [2].

Recently, many studies have explained that obesity has a special relationship with the occurrence of endothelial dysfunction. In a cross-sectional study of 194 patients with overweight and obesity, $50 \%$ of the population has experienced more than average thickening of the intimal carotid arteries and more stiffness in the obese artery wall [3]. Arterial damage in patients with obesity and atherosclerosis is more clearly seen in the coronary arteries than in other arteries [4].

Certain types of plants contain high antioxidative and anti-inflammatory compounds. The bangunbangun (Plectranthus amboinicus [Lour.] Spreng.) plant is widely spread in Indonesia and believed to be a nutritious plant. This plant has a significant association with anti-inflammatory [5], [6], [7], [8], [9], [10], [11] and antioxidative [12], [13], [14] effects.

The primary contents of $P$. amboinicus (Lour.) Spreng that acts against inflammation are fitol, caryophyllene oxide [14], and thymoquinone. These active compounds suppress the expression of proinflammatory cytokines for tumor necrosis factor-alpha (TNF- $\alpha$ ), interleukin (IL)-6, and IL-1 $\beta$ [6]. In mice, the water extract from the leaves of $P$. amboinicus (Lour.) Spreng functions as an anti-inflammatory agent by inhibiting the pro-inflammatory mediators and blocking the activity of NF-kB [8].

The primary antioxidants [15], [16], [17], [18] present in P. amboinicus (Lour.) Spreng are squalene, 
durohydroquinone, timol [19], and carvacrol [14]. The quality and quantity of these compounds vary depending on the region of growth [20], [21], [22], [23]. $P$. amboinicus (Lour.) Spreng, as an antioxidant, increases the activities of the antioxidant enzyme catalase, superoxide dismutase, glutathione peroxidase, lipid peroxidation, and nitric oxide and decreases the activity of glutathione [12].

Diterpenoids, phytol, eugenol, linalool, caryophyllene oxide, and caryophyllene also function against inflammation. Moreover, eugenol, hexadecanoic acid, beta-tocopherol, tetradecanoic acid, and perillic acid have antioxidant activities [14].

Based on the aforementioned description, the researchers aim to analyze the effect of the administration of $P$. amboinicus (Lour.) Spreng ethanol extract on cluster of differentiation (CD40, IL-6, and thickening of the aortic tunica intima in obese mice.

\section{Materials and Methods}

\section{Preparation of $P$. amboinicus (Lour.) Spreng ethanol extract}

The ethanol extract of $P$. amboinicus (Lour.) leaves was cleaned and dried using an oven maintained at $40^{\circ} \mathrm{C}$. The dried simplicia was mashed using a blender until smooth. The dried simplicia powder $(1000 \mathrm{~g})$ was placed into the macerator and added with $10,000 \mathrm{~mL}$ of $70 \%$ ethanol. The marinade was left for $6 \mathrm{~h}$, stirred occasionally, and left for the next $18 \mathrm{~h}$. The leaf immersion macerate was separated using a Whatman filter paper. The search for leaves was repeated by replacing the new $70 \%$ ethanol, but the amount of solvent was half the previous volume of $5000 \mathrm{~mL}$. The process was continued until the macerate was separated. The macerate was collected, concentrated using a rotary evaporator at $30^{\circ} \mathrm{C}-50^{\circ} \mathrm{C}$, and dried using a water bath to obtain the thick ethanol extract of $P$. amboinicus (Lour.) Spreng. The thick extract was suspended with $1 \% \mathrm{Na}-\mathrm{CMC}$ solution [24], [25], [26], [27], [28], [29].

\section{Preparation of animal experiments}

Two-month-old Wistar rats (Rattus norvegicus) were kept in a cage with a daily dark-light cycle for a week for acclimatization. The temperature and humidity of the room were left in the natural range. The twentyfour rats (four rats each group) were fattened using highfat foods for 13 weeks until they were declared obese. The obese criteria in Wistar rat were Lee index $>300$ (cube root of body weight [BW] (g)/nose-to-anus length [cm]) [30]. There are six groups and then food and tap water were given ad libitum. Furthermore, the Wistar rats were given the same food for 45 days [6]. P. amboinicus (Lour.) Spreng extract $(300,600$, and $900 \mathrm{mg} / \mathrm{kg} \mathrm{BW})$ was given to the experimental group each day [9]. The extract was given daily to rats using an oral sonde with the predetermined dose. The treatment groups were C- (negative control), C+ (positive control/cholesterol feed), positive control (cholesterol feed $+\mathrm{CMC}$ ), T1 Chol 300 (cholesterol feed and administration of $300 \mathrm{mg} / \mathrm{kg}$ BW P. amboinicus for 45 days), T2 Chol_600 (cholesterol feed and administration of 600 $\mathrm{mg} / \mathrm{kg}$ BW P. amboinicus for 45 days), and T3_chol_900 (cholesterol feed and administration of $900 \mathrm{mg} / \mathrm{kg}$ BW P. amboinicus for 45 days). This study was approved by the health research ethics committee (No. 0492/ KEPH-FMIPA/2018).

\section{Atherosclerosis biomarkers}

IL-6. Definition: IL-6 is a cytokine secreted in the blood plasma, particularly the acute or chronic phase, and induces an inflammatory response and we measured it with enzyme-linked immunosorbent assay (ELISA). Measuring Instrument: ELISA Reader. Measuring scale: Ratio. Measuring results: $\mathrm{ng} / \mathrm{mL}$ [31].

CD40. Definition: CD40 is a costimulant protein in antigen-presenting cells in the aortic membrane of mice and we measured it with ELISA. Measuring instrument: ELISA Reader. Measuring scale: Ratio. Measuring results: $\mathrm{ng} / \mathrm{mL}$ [32].

Tunica intima thickness. Definition: Tunica intima thickness is the cross-sectional diameter of the aortic blood vessels of obese female mice and we measured it with histopathology. Measurement: A microscope equipped with an ocular micrometer. Measuring scale: Ratio. Measuring results: micron [33], [34].

\section{Data analysis}

The data obtained from the measurement results are expressed in mean \pm standard deviation using Microsoft Excel and analyzed using SPSS. The data did not meet normal data distribution. Therefore, the data were analyzed using the Kruskal-Wallis ANOVA nonparametric test at a confidence level of $95 \%$. Bootstrapping and Duncan tests were also performed. A significant difference was indicated by a significance value of $p<0.05$.

\section{Results and Discussion}

On the basis of the current research, the following points were obtained.

Figure 1 shows that the highest IL- 6 level was observed in the $\mathrm{C}+$ group $(86.63 \pm 67.44 \mathrm{ng} / \mathrm{mL})$, 
which was significantly different from the $\mathrm{C}-(22.78$ $\pm 4.29 \mathrm{ng} / \mathrm{mL}$ ) and T3 Chol 900 (14.79 \pm 11.24) groups but not evidently different from the positive control $(86.73 \pm 50.64 \mathrm{ng} / \mathrm{mL})$, T1_Chol_300 and T2_Chol_600 groups. These results indicated that the administration of high-fat diets can cause inflammation in mice. The excess fat in mice can cause the activation of monocytes into macrophages and eventually leads to inflammation, which causes increased IL-6, inhibits the activity of lipoprotein lipase (LPL), and reduces the differentiation of preadipocytes in humans.

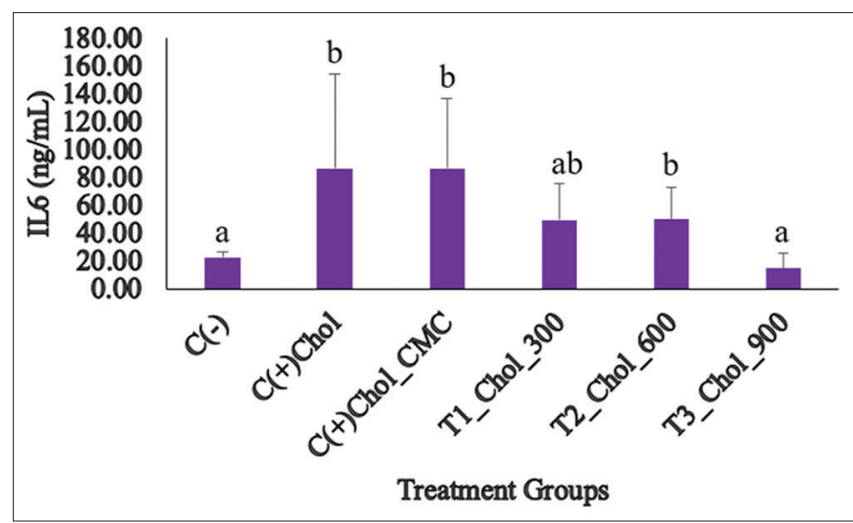

Figure 1: Average levels of interleukin-6 after the administration of the Plectranthus amboinicus (Lour.) Spreng ethanol extract in obese rats

Wang and Nakayama [35], Wang and Butany [36], and Manna and Jain [37] reported that two pathways, namely, stimulating pro-inflammatory activity and increasing systemic oxidative stress, can cause tunica intima dysfunction in obesity. Excess lipids, fatty acids, and cytokines in adipose tissue activate monocytes, which later turn into macrophages to produce various cytokines, such as inflammatory-related adipokines (IL-1, IL-6, and TNF- $\alpha$ ), leptin adiponectin, procoagulant (PAl-1), vasoactive substances (leptin, angiotensinogen, and endothelin), and substances that contribute to insulin resistance (FFA, TNF- $\alpha$, and resistin). IL-1 $\beta$ stimulates NF-kB in the nucleus and induces the transcription of IL-6, COX-2, IL-1Ra, and iNOS.

The addition of extracts in the T3_Chol_900 group significantly reduced the IL-6 level (14.79 \pm $11.24 \mathrm{ng} / \mathrm{mL}$ ), which was significantly different from those of $\mathrm{C}+$, positive control, and T1_Chol_300 groups. This result was caused by the content of flavonoids, fitol, caryophyllene oxide, and thymoquinone in the ethanol extract of $P$. amboinicus (Lour.) Spreng, which functioned as an anti-inflammatory agent. In this case, IL-6 prevented tunica intima dysfunction.

The primary ingredients contained in $P$. amboinicus (Lour.) Spreng as an anti-inflammatory agent is fitol, caryophyllene oxide [14], and thymoquinone. These active compounds suppress the expression of pro-inflammatory cytokines in TNF- $\alpha$, IL-6, and IL-1 $\beta$ [6], [10]). Paniagua [38] stated that IL-6 transcription affects the regulation of C-reactive protein (CRP) and increases fibrinogen and the occurrence of tunica intima dysfunction. Increased TNF-resi expression inhibits the differentiation of adipocyte cell maturity, whereas IL- 6 inhibits the activity of LPL and reduces the differentiation of preadipocytes in humans.

As shown in Figure 2, the administration of cholesterol diets to the mice in the positive control and $\mathrm{C}+$ groups for 45 days resulted in the highest CD40 antibody levels of $63.61 \pm 89.32$ and 44.10 $\pm 20.89 \mathrm{ng} / \mathrm{mL}$, respectively. These results indicated that the administration of high-fat diets can increase oxidative stress, causing inflammation or rat aortic tunica intima lesions. Szmitko et al. [33] stated that tunica intima lesions due to inflammation and increased oxidative stress also express CD40L from the activation of $T$ lymphocytes, platelets, monocytes, and macrophages. In addition, tunica intima lesions are expressed in the form of a solution that is an SCD40L, whose primary source is platelets. By contrast, CD40 is expressed in macrophages, tunica intima cells, vascular smooth muscle cells (VSMCs), and a little in B cells [33].

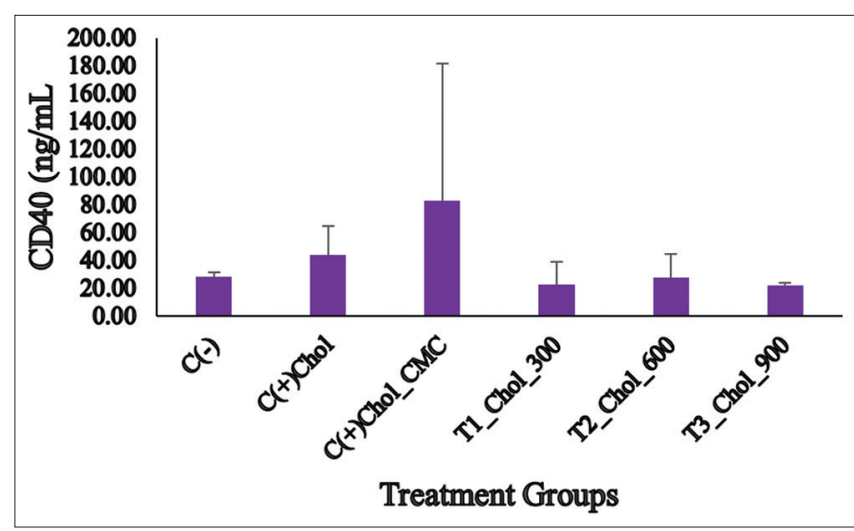

Figure 2: Average plasma CD40 levels after the administration of Plectranthus amboinicus (Lour.) Spreng ethanol extract in obese rats

The administration of $P$. amboinicus ethanol extract at increasing doses $(300,600$, and $900 \mathrm{mg} / \mathrm{kg} \mathrm{BW}$ ) reduced the CD40 levels in blood plasma from $22.30 \pm 16.73 \mathrm{ng} / \mathrm{mL}$ to $22.25 \pm 1.84 \mathrm{ng} / \mathrm{mL}$. This result was due to the presence of antioxidative and antiinflammatory flavonoids and terpenoids in the extract of $P$. amboinicus. Consequently, the CD40 activity decreased and caused reduced lesions or damage to the aortic tunica intima cells. Szmitko et al. [33] stated that the CD40 expression stimulates inflammation. The expressions of CD40L and CD40 can occur at early and advanced atherosclerosis. Lutgens et al. [32] found that the inhibition of CD40L can stabilize plague atherosclerosis by increasing the amount of collagen and VSMC and decreases the number of macrophages and $\mathrm{T}$ lymphocytes. CD40L can work when bound by CD40 as a receptor, resulting in marking activity on the process of atherosclerosis in the aortic tunica intima.

The highest aortic tunica intima thickness of mice (Figure 3) was observed in the $\mathrm{C}+$ group (7.92 \pm $0.66 \mu \mathrm{m})$, which was significantly different from the $\mathrm{C}$ group (without high-fat diet) $(4.76 \pm 1.98 \mu \mathrm{m})$ and not significantly different from the positive control $(6.44$ 


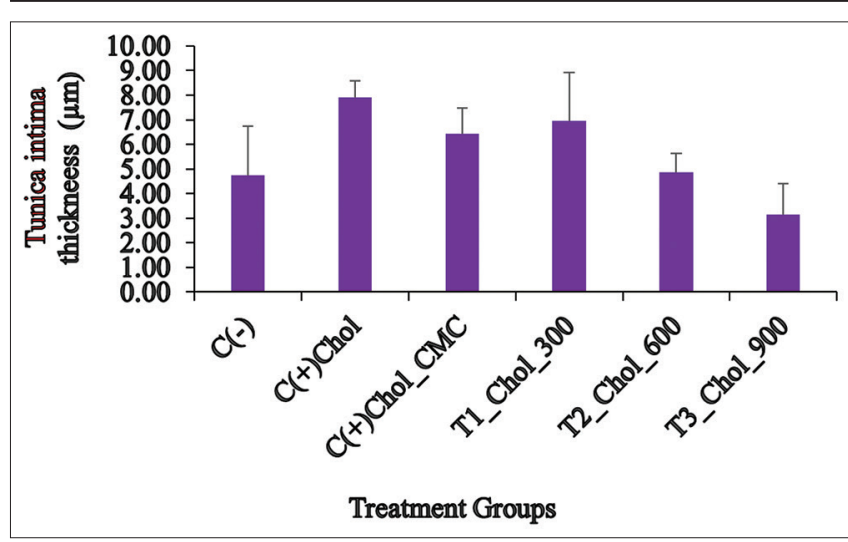

Figure 3: Average tunica intima thickness after the administration of Plectranthus amboinicus (Lour.) ethanol extract in obese rats

$\pm 1.04 \mu \mathrm{m})$ and the T1_Chol_300 (6.94 $\pm 1.99 \mu \mathrm{m})$ groups. These results showed that a high-fat diet (hypercholesterolemia) can increase the thickness of the rat aortic tunica intima. Increased fat, particularly low-density lipoprotein, can cause changes in the adhesion power of leukocyte cells to aortic tunica intima cells. Oxidative stress (reactive oxygen species [ROS]) was increased through increased angiotensin II and can eventually lead to atherosclerotic lesions.

Two pathways, namely, stimulating proinflammatory activity and increasing systemic oxidative stress, can cause endothelial dysfunction in obesity. Excess lipids, fatty acids, and cytokines in the adipose tissue activate monocytes, which later turn into macrophages to produce various cytokines, such as inflammatory-related adipokines (interleukin-1 [IL-1], IL-6, and TNF- $\alpha$ ), leptin adiponectin, PAI-1, vasoactive substances (leptin, angiotensinogen, endothelin), and substances that contribute to insulin resistance (FFA, TNF- $\alpha$, and resistin). IL-1 $\beta$ stimulates NF-kB in the nucleus and induces the transcription of IL-6, COX-2, IL-1Ra, and iNOS. IL-6 transcription affects the regulation of CRP and increases fibrinogen and the occurrence of endothelial dysfunction [35], [36], [37]. Increased TNFresi expression inhibits the differentiation of adipocyte cell maturity, whereas IL-6 inhibits the activity of LPL and reduces the differentiation of preadipocytes in humans [38].

Endothelial lesions due to inflammation and increased oxidative stress express CD40 ligands (CD40L) from the activation of T lymphocytes, platelets, monocytes, and macrophages. In addition, endothelial lesions are expressed in the form of a solution that is a soluble CD40L (sCD40L), whose primary source is platelets. By contrast, a CD40 is expressed in macrophages, endothelial cells, VSMCs, and a little in B cells. CD40 expression stimulates inflammation. The expression of CD40L and CD40 can occur in early and advanced atherosclerosis [33]. The inhibition of CD40L can stabilize plague atherosclerosis by increasing the amount of collagen and VSMC and decreasing the number of macrophages and T lymphocytes [32].
Szmitko et al. [33] found that hypercholesterolemia increases the attachment of blood leukocytes to the tunica intima, the cell layer that is normally resistant to strong leukocyte adhesion. Oxidized low-density lipoprotein causes tunica intima activation and alters its biological characteristics by reducing intracellular NO concentration. Angiotensin II, a vasoconstrictor associated with hypertension, has an opposite action with NO. Angiotensin II can cause the production of ROS, increase the expression of pro-inflammatory cytokines (IL6) and monocyte chemoattractant protein-1, and increase the regulation of vascular cell adhesion molecules in ECs. Newer risk factors, such as increased levels of CRP, can also increase tunica intima dysfunction by quelling NO production and reducing its bioactivity. This tunica intima modification stimulates inflammation in the walls of blood vessels, thereby regulating the rate of initiation and development of atherosclerotic lesions.

The administration of $P$. amboinicus ethanol extract at doses of 600 and $900 \mathrm{mg} / \mathrm{kg}$ BW causes a significant reduction in the rat aortic tunica intima thickness $(4.86 \pm 0.77 \mu \mathrm{m} ; 3.14 \pm 1.25 \mu \mathrm{m})$ compared with $\mathrm{C}-(4.76$ $\pm 1.98 \mu \mathrm{m}), \mathrm{C}+(7.92 \pm 0.66 \mu \mathrm{m})$, and $\mathrm{C}+$ (positive control/ cholesterol feed) $(6.44 \pm 1.04 \mu \mathrm{m})$ (Figure 4).

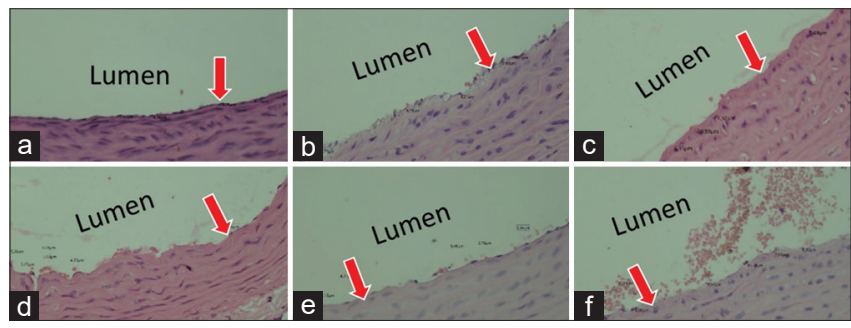

Figure 4: Histological image of the tunica intima (red arrow) of obese rats after the administration of Plectranthus amboinicus (Lour.) Spreng ethanol extract. (a) C-, (b) C+, (c) positive control, (d) T1 Chol_300, (e) T2_Chol_600, and (f) T3_Chol_900. Magnification $\times 400, H E$

\section{Conclusion}

The ethanol extract of $P$. amboinicus leaves can significantly decrease the level of CD40, IL-6, and the thickness of the tunica intima blood vessels that result in the group of obese rats and became normal.

\section{References}

1. World Health Organization. Global Status Report on Noncommunicable Disease 2014, Attaining the Nine Global Noncommunicable Disease Targets; a Shared Responsibility. Geneva, Switzerland: World Health Organization; 2014. 
2. Cheong WS. Overweight and Obesity in Asia, Genre. United States: A Berkshire Hathaway Company; 2014. Available from: http://www.genre.com/knowledge/publications/ufocus14-2cheong-en.html. [Last accessed on 2020 Jan 05]

3. Megias-Rangil I, Merino J, Fere R, Plana N, Heras M, Cabre A, et al. Subclinical atherosclerosis determinants in morbid obesity. Nutr Metab Cardiovasc Dis. 2014;24(9):963-8. https://doi. org/10.1016/j.numecd.2014.04.012

4. Rodriguez-Flores M, Rodriguez-Saldana J, Cantu-Brito C, Aguirre-Garcia J, Alejandro G. Prevalence and severity of atherosclerosis in different arterial territories and its relation with obesity. Cardiovasc Pathol. 2013;22(5):332-8. https://doi. org/10.1016/j.carpath.2013.01.008

\section{PMid:23465353}

5. Muniroh L, Martini S, Nindya TS, Solfaine R. Efek anti radang dan toksisitas akut ekstrak daun jinten (Plectranthus amboinicus) pada tikus yang diinduksi arthritis. Makara Seri Kesehatan. 2013;17(1):33-40. https://doi.org/10.7454/msk.v17i1.2008

6. Chang JM, Cheng CM, Hung LM, Chung YS, Wu RY. Potential use of plectranthus in the treatment of rheumathoid arthritis. eCAM. 2007;7(1):115-20.

7. Hutapea A, Hutahaean S, Ilyas S. Influence of pirdot lea (Saurauia vulcani, Korth.) extract on the blood glucose rate and histologic description of the retina of male mice (Mus musculus strain DDW). Asian J Pharm Clin Res. 2018;11(11):389-92. https://doi.org/10.22159/ajpcr.2018.v11i11.28316

8. Chiu YJ, Huang TH, Chiu CS. Analgesic and antiinflammatory activities of the agueous extract from Plectranthus amboinicus (Lour.) Spreng. Both in vitro and in vivo. Evid Based Complement Altern Med. 2012;2012:508137. https://doi. org/10.1155/2012/508137

PMid:21915187

9. Kuo YS, Chien HF, dan Lu W. Plectranthus amboinicus and Centella cream for the treatment of diabetic foot ulcers. Evid Based Complement Altern Med. 2012;2012:418679. https://doi. org/10.1155/2012/418679

10. Chen YS, Yu HM, Shie JJ, Cheng TJ, Wu CY, Fang JM, et al. Chemical constituents of Plectranthus amboinicus and the synthetic analogs possessing anti-inflammatory activity. Bioorg Med Chem. 2014;22(5):1766-72. https://doi.org/10.1016/j. bmc.2014.01.009

PMid:24491635

11. Sengupta R, Sheorey SD, Hinge MA. Analgetik and antiinflamatory plants: An updated review. Int J Pharm Sci Rev Res. 2012;12:114-7.

12. Ilyas S, Hutahaean S, Nursal N. Quantity and quality of guinea pig (Cavia porcellus) spermatozoa after administration of methanol extract of bitter melon (Momordica charantia) seed and depot medroxy progesterone acetate (DMPA). IOP Conf Ser Earth Environ Sci. 2018;130(1):012047. https://doi. org/10.1088/1755-1315/130/1/012047

13. Arumugam G, Swamy MK, Sinniah UR. Plectranthus amboinicus (Lour.) spreng: Botanical, phytochemical, pharmacological and nutritional significance. Molecules. 2016;21(4):369. https://doi. org/10.3390/molecules21040369

PMid:27043511

14. Uma M, Jothinayaki S, Kumaravel S, Kalaiselvi P. Determination of bioactive component of Plectranthus amboinicus lour by GC-MS analysis. N Y Sci J. 2011;4(8):66-9.

15. Masyithah $\mathrm{C}$, Hadisahputra $\mathrm{S}$, Ilyas $\mathrm{S}$. Combinational effects of ethylacetate extract of Zanthoxylum acanthopodium DC. With doxorubicinon MCF7 breast cancer cells. Int J PharmTech Res. 2015;7(4):651-3.

16. Hasibuan R, llyas S, Hanum S. Effect of leaf extract haramonting (Rhodomyrtus tomentosa) to lower blood sugar levels in mice induced by alloxan. Int J PharmTech Res. 2015;8(6):284-91.
17. Ilyas S, Hutahaean S, Nursal N. Apoptosis overview of cerebellum Purkinje cell in mice (Mus musculus L.) after exposure to methanol extract of the seeds of bitter melon (Momordica charantia) and DMPA. Int J PharmTech Res. 2016;9(9):1-8. https://doi.org/10.22159/ajpcr.2018.v11i12.27920

18. Irianti E, Ilyas S, Rosidah R, Hutahaean S. Hsp70 expression profile in preeclampsia model of pregnant rat (Rattus norvegicus) after giving the evoo. IOP Conf Ser Mater Sci Eng. 2017;180(1):012161. https://doi. org/10.1088/1757-899x/180/1/012161

19. Roshan P, Naveen M, Manjul PS, Gulzar A, Anita S, Sudarshan S Plectranthus amboinicus (Lour) Spreng: An overview. Pharma Res. 2010;4:1-15.

20. Ilyas S, Tanjung RS, Thahira D, Wulandari J. Effectiveness of administration haramounting leaf (Rhodomyrtus tomentosa) as antioxidant in preventing the damage pancreas mice (Mus musculus L.) after exposure of electric cigarette smoke. J Phys. 2018;1116(5):052084. https://doi. org/10.1088/1742-6596/1116/5/052084

21. Ilyas S. Histological changes in the testis if the guinea pig during administration of methanol extract of bitter melon (Momordica charantia L.) seed and DMPA. J Phys. 2018;1116(5):052031. https://doi.org/10.1088/1742-6596/1116/5/052031

22. Ilyas S, Tanjung M, Nurwahyuni I, Pasaribu FY. Effect of mahkota dewa ethanolic extracts (Phaleria macrocarpa Scheff.) to hepar histology of female rat (Rattus novergicus) in preeclampsia. IOP Conf Ser Earth Environ Sci. 2019;305:012075. https://doi. org/10.1088/1755-1315/305/1/012075

23. Ilyas S, Tanjung RS, Hutahaean S, Tanjung M, Elimasni E, Jamilah I, et al. Antioxidant activity of haramounting leaf ethano extract (Rhodomyrtus tomentosa) in preventing heart damage of mice (Mus musculus L.) after exposure to electronic cigarette. IOP Conf Ser Earth Environ Sci. 2019;305(1):012080. https:// doi.org/10.1088/1755-1315/305/1/012080

24. Sinaga E, Ilyas S, Hutahaean S, Sitorus P. Immunostimulatory activity from pirdot leaves ethanolic extract (Saurauia vulcani Korth.) in Rats (Rattus norvegicus). IOP Conf Ser Earth Environ Sci. 2019;305(1):012082. https://doi. org/10.1088/1755-1315/305/1/012082

25. Ilyas S, Murdela F, Hutahaean S, Situmorang PC. The effect of haramounting leaf ethanol extract (Rhodomyrtus tomentosa (Aiton) Hassk.) on the number of leukocyte type and histology of mice pulmo (Mus musculus L.) exposed to electronic cigarette. Open Access Maced J Med Sci. 2019;7(11):1750-6. https://doi. org/10.3889/oamjms.2019.467

PMid:31316653

26. Sabri E, llyas S, Prasetiawan E. The effect of n-hexane extract of andaliman (Zanthoxylum acanthopodium DC.) fruit in the liver tissues of mice during post implantation of pregnancy. J Phys. 2018;1116(5):052056. https://doi. org/10.1088/1742-6596/1116/5/052056

27. Hutahaean S, Banjarnahor RD, Darsini P, Ilyas S, Sabri E. The effect of Saurauia vulcani Korth. leaves extract on penile corpus cavernosa microstructure and the quality of sperm in alloxaninduced diabetic mice. J Phys. 2018;1116(5):052030. https:// doi.org/10.1088/1742-6596/1116/5/052030

28. Ilyas $S$, Hutahaean $S$, Nursal N. Transforming growth factor beta of testis germinal cell in Guinea pig (Cavia porcellus) after exposure to methanol extract of the seeds of bitter melon (Momordica charantia) and depot medroxyprogesterone acetate. Asian J Pharm Clin Res. 2018;11(12):149-54. https:// doi.org/10.22159/ajpcr.2018.v11i12.27920

29. Silitonga $M$, llyas $S$, Hutahaean S, Sipahutar H. Level of apigenin and immunostimulatory activity of leaf extracts of Bangun-Bangun (Plectranthus amboinicus Lour). Int $\mathrm{J}$ Biol. 2015;7:46. https://doi.org/10.5539/ijb.v7n1p46

30. Favero G, Lonati C, Giugno L, Castrezzati S, Rodella LF 
Rezzani R. Obesity-related dysfuntion of the aorta and prevention by melatonin treatment in ob/ob mice. Acta Histochem. 2013;115(8):783-8. https://doi.org/10.1016/j.acthis.2013.02.014

31. Vainer N, Dehlendorff C, Johansen JS. Systematic literature review of IL-6 as a biomarker or treatment target in patients with gastric, bile duct, pancreatic and colorectal cancer. Oncotarget. 2018;9(51):29820-41. https://doi.org/10.18632/ oncotarget.25661

PMid:30038723

32. Lutgens E, Lievens D, Beckers L, Marjo D, Daemen M. CD40 and its ligand in atherosclerosis. Trends Cardiovasc Med. 2007;17(4):118-23. https://doi.org/10.1016/j.tcm.2007.02.004 PMid:17482093

33. Szmitko PE, Wang CH, Weisel RD, Almeida JR, Anderson TJ. New marker of inflammation and endothelial cell activation: Part I. Circulation. 2003;108(16):1917-23. https://doi.org/10.1161/01. cir.0000089190.95415.9f

PMid:14568885
34. Smiljic S, Mijovic M, Savic S. Biomarker of endothelial dysfunction in cardiovascular disease. Med Pregl. 2017;12:53-7. https://doi.org/10.2298/mpns1702053s

35. Wang Z, Nakayama T. Inflammation, a link between obesity and cardiovascular disease. Mediators Inflamm. 2010;2010:535918. PMid:20847813

36. Wang T, Butany J. Pathogenesis of atherosclerosis. Diagn Histopathol. 2017;11:009.

37. Manna P, Jain SK. Obesity, oxidative stress, adipose tissue dysfunction, and the associated health risks: Caauses and therapeutic strategies. Metab Syndr Relat Disord. 2015;13(10):423-44. https://doi.org/10.1089/met.2015.0095 PMid:26569333

38. Paniagua JA. Nutrition, insulin resistance and dysfunctional adipose tissue determine the different components of metabolic syndrome. Word J Diabetes. 2016;7(19):483-514. https://doi. org/10.4239/wjd.v7.i19.483

PMid:27895819 